\title{
A Right to Access to Medical Records in the Case Law of the Portuguese Courts: Possible Guidelines for future European Court of Human Rights Case Law
}

\author{
By Anatoliy A. Lytvynenko*
}

\begin{abstract}
Patients frequently strive to access their respective medical records before commencing a malpractice action against hospitals or physicians, though the aim of the inspection of these records may extend to other civil litigation or private discovery issues. In contrast to well-known issues within medical law, such as medical malpractice or informed consent, litigation concerning the patient's (and occasionally others, as well) right to inspect their medical records does not possess a rich history in case law, and this lacuna is reflected by the lack of legislative acts and bylaws in some jurisdictions. The litigation regarding access to health records has given rise to various complicated issues that are related to data privacy and medical record-keeping. These may involve matters such as the proprietary status of medical records, the right to third parties' inspection of records or a right to access a deceased relative's medical records, the transfer of medical records from one health-care provider to another and the scope of medical records that are eligible to be inspected. The European Court of Human Rights has also dealt with the issue, most recently in $K \&$ Others $v$. Slovakia, where the Court ultimately recognised the patient's right to inspect their medical records as covered by the scope of Art. 8 of the European Convention of Human Rights. Although the European Court has dealt with the issue intermittently, there are still many unresolved aspects that may be brought before the Court. This paper presents the general issues of access to medical records' litigation, including a case study of judgments promulgated by the courts of Portugal on the subject, wherein the Portuguese courts adopted a series of principles that may be crucial for further litigation not only in Portuguese courts or the national courts of neighbouring states, but in international Human Rights Courts as well.
\end{abstract}

Keywords: Access to Medical Records; Medical Confidentiality; Data Privacy; Medical Records.

\section{Introduction - General Assumptions on the Right to Medical Records Inspection}

Over the last decades, the jurisprudence of various civil and common law jurisdictions has reflected the development of the concept of a patient's right to decision-making and autonomy. This is, inter alia, was accompanied by their right

*PhD (Law) Candidate, Ivan Franko National University of Lviv, Ukraine.

E-mail: anat.lytvynenko@gmail.com. 
to inspect their medical records, which commonly include information regarding their current state of health, treatments, analyses, diagnostics, and prognosis of their future health condition. ${ }^{1}$ In fact, the patient's personal data may include a large amount of recorded textual data, or other physician-identifiable data recorded by means of diagnostics, which are not necessarily textual ${ }^{2}$ but may be identifiable by expert physicians or by specific techniques. For instance, a relatively recent judgment by the Stockholm Court of Appeals decreed that a list of medicines prescribed to a patient was also considered part of their medical data. ${ }^{3}$ In some civil law states, such as Germany, this right is not codified and is determined by the Courts as a right deriving from the contract between the patient and the physician or hospital. ${ }^{4}$ Common law states, such as England, have adopted a socalled "common-law" right to access medical records, ${ }^{5}$ though commentators had claimed that even in common law situations, the purpose of accessing these records has rarely been for malpractice litigation. ${ }^{6}$ Some states, such as Portugal, have adopted legislation that guarantees the right to access medical records, later considering them as administrative records (in the same way as some United States Courts recognised medical records as quasi-public, ${ }^{7}$ or public records). ${ }^{8}$ As a result, access to these records may be obtained based on the law regarding access to administrative documents. ${ }^{9}$ However, in most cases where the prospective plaintiff requests that the hospital allow them access to their health records, this occurs in preparation for a malpractice action. ${ }^{10}$ These include:

\footnotetext{
${ }^{1}$ In Germany, courts referred to medical records as data concerning the patient's current condition and the prognosis for the future, see judgment of the Bremen's Higher Regional Court, OLG Bremen, 31.07.1979 - 1 U 47/79, at para. 15. In Portugal, this definition seems to be a bit broader, see. Unidade de Saude A c. B..., Acordao do Supremo Tribunal Administrativo, 08.08.2018, Processo 0394/18, Sec. II, 1-11. In more contemporary case law of German courts, they extended the definition by adding, that "In addition to the medical, objectifiable findings and reports on [the patient's] treatment measures, such as surgery and medication [it includes] the description of subjective perceptions [obviously, of the physicians] and personal [physician's] impressions of the patient", see OLG Karlsruhe, Urt. v. 16.08.2017 - 7 U 202/16, at para. 22.

${ }^{2}$ See my comments concerning defining "medical data" in Lytvynenko (2020a) at 102-103 and cases cited therein.

${ }^{3}$ Socialnämnden i Danderyds kommun, Kammratt Stockholm, 17 Sep. 2014, fall 5348-14 (2014)

${ }^{4}$ Particularly affirmed by the Decision of Federal Supreme Court of Germany, BGH 28.11.1982, VI ZR 222/79, at para. 15; see also the following judgments: $A G$ Weltzar, 15.08.1978 - 3C 707/78, para. 8-9 та 15; LG Gottingen, 16.11.1978 - 2 O 152/78, para. 9-10, 16; BGH, 23.11.1982; VI ZR 222/79, para. 14-15; AG Essen, 21.04.1997 - 12 C13/97, para. 5-6; OLG Munchen, 19.04.2001 - 1 U 6107/00, para. 21.

${ }^{5}$ Ex parte Martin, [1995] 1 W.L.R. 110, 117-119.

${ }^{6}$ Feenan (1996) at105-107.

${ }^{7}$ Pyramid Life Insurance Co. v. Masonic Hospital Assn. of Payne County 191 F. Supp. 51, 54 (W.D. Okla. 1961).

${ }^{8}$ Oliver v. Harborview Medical Center, 94 Wash.2d 559, 564-567 (1980).

${ }^{9}$ Unidade de Saude A c. B..., Acordao do Supremo Tribunal Administrativo, 08.08.2018, Processo 0394/18, Sec. III, 2.

${ }^{10}$ In fact, such purpose is the most common reason for an inspection of medical records among common law and civil law states. For instance, see England: Dunning v United Liverpool Hospitals' Board of Governors, [1973] 1 W.L.R. 586; Deistung v South West Metropolitan Regional Hospital Board, [1974] 1 W.L.R. 213; Davidson v Lloyd Aircraft Services Ltd., [1974] 1 W.L.R. 1042; and e.g. Germany, see. e.g. OLG Köln, 12.11.1981: 7 U96/81, at para. 18. The same applies to Portugal:
} 
1. Medical malpractice action, such as an action for battery (unauthorised surgical intervention with no informed consent) $;^{11}$

2. Access to a deceased relative's health records so as to determine if the cause of death is a result of the negligence of healthcare workers; ${ }^{12}$

3. Access to the deceased testator's health records in order to challenge the validity of their will, or specific codicils of the will. Such judgments could be found in the case law of the Netherlands ${ }^{13}$ and Germany; ${ }^{14}$

4. A private discovery of facts concerning a plaintiff's treatment, e.g. in mental asylums (this is quite rare in case law, though there are a number of examples from Germany); ${ }^{15}$

5. A plaintiff's wish to uncover the identity of their biological parents; ${ }^{16}$

6. A necessity to produce medical records for a divorce trial before a diocese court. As I discussed in a recent paper, this occurs mainly in Italy. ${ }^{17}$

In many cases, inspecting medical records is prohibited for various reasons. For instance, in the mid-1970s, English Courts determined that the plaintiff should not be allowed to directly inspect their medical records, as this was a right reserved exclusively for lawyers or appointed medical advisors. ${ }^{18}$ English courts were eager to follow the then-existing hospital practices and decided not to grant plaintiffs the right to read or copy material from their medical records. This decision was based upon the argument that laymen may not properly understand the medical documentation, the prognosis of the patient's health condition may be too harsh to be properly communicated, the plaintiff or their relatives may find them embarrassing and lastly, some records may be highly confidential, which if breached, may prevent doctors from expressing their views "fully and frankly."19 Much of this position was also adopted by the Portuguese courts, though later in this paper I will discuss certain specific restrictions elaborated upon by these

Unidade de Saude A c. B..., Acordao do Supremo Tribunal Administrativo, 08.08.2018, Processo 0394/18, Sec. III, 4.

${ }^{11}$ See, e.g. the judgment of the European Court of Human Rights in the case of K. H. \& Others $v$. Slovakia, App. no. 32881/04, Judgment of 28 March 2009, at para. 8-9.

${ }^{12}$ See Judgment of the Federal Supreme Court of Germany of 1983, BGH, 31.05.1983 - VI ZR 259/ 81 at para. 17.

${ }^{13}$ Hoge Raad, 20 April 2001, NJ 2001, 600; No. C99/030 HR, para. 3.1; 3.2 (facts); Rechtbank Arnhem, 8 August 2005, Prg. 2005, 195, No. 128531 (see Section "Dispute" para. 1-4; "The assession of the dispute", para. 4 (including the subparagraphs).

${ }^{14}$ See $O L G$ Düsseldorf, Urt. v. 29.03.2000, Az.:3 Wx 436/99 at para. 12-19.

${ }^{15}$ See judgment of the German Federal Supreme Court, BGH, 02.10.1984 - VI ZR 311/82, originally page 5-8 from the court report.

${ }^{16}$ In one of my recent works, I have described the concept of "a right to anonymous birth" from its very beginning in French and Belgian case law originating from mid- $19^{\text {th }}$ century, as well as an analysis of contemporary case law on the subject from United States and Italy, as well as two judgments of the European Court of Human Rights. See in detail Lytvynenko (2020a) at 124-131.

${ }^{17}$ F.M. contro Casa di Cura Polispecialistica (...) e M.I., Consiglio di Stato, Sezione V., sentenza 28 settembre 2010, no. 7166 .

${ }^{18}$ See Deistung $v$ South West Metropolitan Regional Hospital Board, [1974] 1 W.L.R. 213, at p. 215-217.

${ }^{19}$ See McIvor v Southern Health \& Social Service Board, [1978] 1 W.L.R. 757, at p. 760-761. 
courts. ${ }^{20}$ German courts, on the other hand, seem to be more liberal regarding the restriction of access to medical records. In the decision of the Higher Regional Court of Cologne (Oberlandesgericht Koln) of 1981, for example, the Court determined that in the case of a patient lacking sufficient knowledge in interpreting medical records, they are free to employ lawyers and medical advisors for assistance. $^{21}$ This was not the first case where a German court rejected the argument that it was permissible to restrict the communication of data to a patient based on the argument that a patient might not be able to properly understand their record. In 1978, an appellate court in Gottingen held that the plaintiff was entitled to employ advisors to decipher and explain their medical records. ${ }^{22}$ In its 1982 judgment, the German Federal Supreme Court, affirming the position of the aforementioned court of Cologne, also held that often medical records are intelligible even to laymen. ${ }^{23}$ This court found that the only applicable restriction regarding access to a patient's medical records may concern communications between physicians, involving supposed diagnoses or containing subjective language. The Court thus agreed that scientific findings might be accessible to patients. ${ }^{24}$ However, German courts (particularly, the Federal Supreme Court) affirmed that there may be some categories of medical data that merited specific or partially restricted access, referring mainly to psychiatric records ${ }^{25}$. In such cases, the plaintiff may be compelled to justify their reasons for requesting access to medical records (e.g. to produce them within the framework of malpractice litigation), ${ }^{26}$ though in ordinary circumstances, not all courts may ask for such justification. Such was the position of the German Federal Supreme Court in two 1980s judgments. ${ }^{27}$ This form of justification is also relevant to cases where the relatives of a deceased person desire to examine the records so as to determine the cause of their death and subsequently sue the hospital for negligence. ${ }^{28}$

\section{A Brief History}

While some commentators believe that the right to access medical records was not known within the framework of common law before the 1960s or 1970s, ${ }^{29}$ the long-standing interest in this subject is demonstrated by hospital record-

\footnotetext{
${ }^{20}$ B c. C., Acordao do Tribunal da Relacao do Porto, 08.09.2019, Processo No. 2147/18.T8AGD. $\mathrm{P} 1$, Sec. II.

${ }^{21}$ OLG Koln, 12.11.1981, 7U 96/81 at para. 24-25.

${ }^{22} L G$ Gottingen, $16.11 .1978-20152 / 78$ at para. 9-16.

${ }^{23} B G H, 23.11 .1982$; VI ZR 222/79 at para. 17-27.

${ }^{24}$ Same, see BGH, 23.11.1982; VI ZR 222/79 at para. 17-27 and 30.

${ }^{25}$ See judgment of the German Federal Supreme Court, $B G H, 06.12 .1988$ - VI ZR 76/88, at para. 7, 9-10.

${ }^{26} L G$ Saarbrucken, 20.09.1995 - $16 \mathrm{~S}$ 1/93, at para. 7-8

${ }^{27}$ See. $B G H, 31.05 .1983$ - VI ZR 259/81, at para. 8; $B G H, 02.10 .1984$ - VI ZR 311/82, original judgment report at p. 5 .

${ }^{28}$ See judgment of the German Federal Supreme Court of 1983, BGH, 31.05.1983 - VI ZR 259/81, at para. 19-20.

${ }^{29}$ See comment of the House of Lords in McIvor v Southern Health \& Social Service Board [1978] 1 W.L.R. 757 at p. $760-761$.
} 
keeping practices. In countries such as Germany and Austria, hospital recordkeeping practices began no later than the seventeenth century, and were monitored by local authorities in order to avoid malpractice. ${ }^{30}$ However, issues concerning the validity of medical certificates, as well as the forgery of medical records, can be found in the earlier case law of France. ${ }^{31}$ In the nineteenth-century jurisprudence of France, medical secrecy was deemed as non-negotiable, and the courts were reluctant to recognise exceptions until the early twentieth century. ${ }^{32} \mathrm{In}$ the late nineteenth and early twentieth century, the French courts found that in certain circumstances, such as proving an infant's cause of death ${ }^{33}$ or challenging the validity of a will, ${ }^{34}$ producing medical records was permissible and did not contradict the rules of medical secrecy. ${ }^{35}$ The Belgian rules regarding medical confidentiality seem to be less stringent, ${ }^{36}$ and as far back as 1855 , the Belgian Cassational Court denied a physician the right to conceal the identity of the mother of an illegitimate child. ${ }^{37}$ In other cases, where healthcare workers applied to the court to obtain remuneration for the medical care they had provided to a deceased person, the plaintiffs were prohibited from discussing the symptoms of the deceased's last disease before court experts, as this would breach medical confidentiality. $^{38}$

Another, more complicated issue, was the patient's right to control the transmission of their medical records to third parties, enterprises, or public bodies. For instance, in a case resolved by the Lyon Court of Appeals in 1909, a factory worker sued a physician for entering the fact that he had contracted syphilis into his medical record and delivering it to the factory's insurance fund, preventing him from receiving indemnities for his treatment and disability. The Court held that it was not a violation of medical secrecy to do so; interestingly, the plaintiff did not sue the physician for violation of medical secrecy, but for misdiagnosis. ${ }^{39}$ In a judgment of the Swiss Federal Tribunal from 1917, a misfortunate serviceman fell

\footnotetext{
${ }^{30}$ Gründling (2011) at 32-35.

${ }^{31}$ Min. Publ. c. Doumayrou, Cour de Cass., Cham. crim. 6 Mai 1836, Dall. Per. 1837 I 246.

${ }^{32}$ See in particular Lytvynenko (2020a) at 106-110 and cases cited therein.

${ }^{33}$ Carron c. Vallaton, Cour d'Appel de Lyon, 24 Mars. 1876, Sirey 1877 II 200.

${ }^{34}$ Cons. Aubertin c. v. Perrin, Trib. de Bar-Le-Duc, 15 Oct. 1913, Sirey 1914 II 13.

${ }^{35}$ But at the same time, it should be denoted that the rules of medical secrecy was not always consistent among all the French courts. For instance, in Bousquet c. Compaigne le Gresham, Cour de Cass., Cham civ., 1 Mai 1899, Dall. Per. 1899 I 585, 587, the French Cassational Court excluded physician's testimony concerning the insured man's ailment (which, if found to be admissible, could eliminate plaintiff's claim in the policy repayment, as the insured man died owing to health complexification - this case is commented upon in one of my recent works, Lytvynenko (2020a) at 107.

${ }^{36}$ In the "trial of duellants", dated 1845, the Brussels Court of Appeal dealed with a case where a doctor who assisted a wounded duellant (in fact, the duel, being already illegitimate in Belgium those days, was conducted between two noblemen - Baron d'Hogvorst and Albert Joseph Goblet d'Alviella), refused to answer the question concerning the character of the wound and similar interrogations by the court. He was prosecuted and made to testify, Min. Publ c. Seutin, Cour d'Appel de Bruxelles, 25 mai 1845, Pas. 1845 II 307, 307-308.

${ }^{37}$ Bessems c. Le Ministere Public, Cass. 20 juillet 1855, Pas. 1855 I 303, 305-307; 308-309.

${ }^{38}$ Bernardine de Neef c. Camille Moreau et Consorts, Cour d'Appel de Bruxelles, 24 mars 1905, BJ 1905.530, 530-532.

${ }^{39}$ G. c. R., Cour d'Appel de Lyon, 16 juin 1909, Dall. Per. 1910 II 123, 124-125.
} 
ill after returning from service. His doctor and the doctor's assistant concluded that his illness might be a result of the complications of alcoholism and delivered copies of the plaintiff's medical record to his relatives. The man sued the doctor and his assistant for disclosing his record to his relatives, demanding $5000 \mathrm{CHF}$ and the production of the original medical documents. In addition, it turned out that the doctor's assistant (the second defendant) reached the wrong conclusion concerning the cause of the plaintiff's illness, as subsequently the plaintiff's physical situation improved. The trial court held that the physician acted in good faith and had no intention of harming the plaintiff, despite having entered a misdiagnosis in the medical certificate, and decided in favour of the defendants. On appeal, the Federal Tribunal found that the defendants violated Art. 28 of the Swiss Civil Code (Code Civile Suisse) ${ }^{40}$, but chose not to compel them to pay damages, as the Court found that there was no significant gravity in the acts of the defendants, though the Court did obligate them to provide the plaintiff a copy of the original certificate. ${ }^{41}$

In the United States, the first actions against hospitals and physicians requesting the production of medical records occurred in the late 1930s and were entirely dictated by the plaintiff's wish to produce evidence for malpractice litigation. $^{42}$ This soon became the most common, and, in fact, nearly the only reason, ${ }^{43}$ for requesting medical records not only in the United States. By the early 1970s, this was also true for England. ${ }^{44}$

Some countries, such as Germany ${ }^{45}$ and Austria, ${ }^{46}$ held that the right to view medical records derives from the contract between the physician/hospital and the patient, which has never been codified. Some German courts have deemed that the patient may obtain their medical records even though the contract may not necessarily contain provisions regarding the patient's right to view their medical records. ${ }^{47}$ Much has been written about the implications of the patient-physician relationship, ${ }^{48}$ which many agree has always been contractual by legal nature both in common law $^{49}$ and civil law jurisdictions. Switzerland ${ }^{50}$, Germany ${ }^{51}$ and

\footnotetext{
${ }^{40}$ RO 210, Code civil suisse du 10 decembre 1907, Art. 28.

${ }^{41}$ H. c. M. et V., Arret de la Ire Section civile du 25 octobre 1918, BGE 44 I 322, 325; 327-328

${ }^{42}$ See for instance Lytvynenko (2019) at 202.

${ }^{43}$ However, in some instances, access to medical records (especially to third parties) was restricted to avoid abuse of process, see, e.g. Church of Scientology v DHSS, [1979] 1 W.L.R. 723, 728 onward.

${ }^{44}$ See., for instance, the case of Dunning vUnited Liverpool Hospitals' Board of Governors, [1973]

1 W.L.R. 586.

${ }^{45}$ See particularly the decision of German Federal Supreme Court, BGH, 23.11.1982; VI ZR 222/79, at para. 15 .

${ }^{46}$ See decision of the Austrian Supreme Court (Oberster Gerichthof), OGH 23.5.1984, 1 Ob 550/84.

${ }^{47}$ See decision of the German Federal Supreme Court, BGH, 31.05.1983 - VI ZR 259/81, at para. 12

${ }^{48}$ See Kenna (1973) at 322.

${ }^{49}$ A good example in $20^{\text {th }}$ century US case law is Agnew v. Parks, 172 Cal. App. 2d 756, 764 (1959). In an early Canadian case, Lavere v Smith's Falls Public Hospital, 26 D.L.R. 346 (1915), the Supreme Court of Ontario discusses contractual liability of hospitals for negligent care and treatment to patients, and gives various examples of early English, Irish, Scottish and US case law on the subject, see particularly from page $351\left(26^{\text {th }}\right.$ vol. of Dominion Law Reports, Ser. 1).

${ }^{50}$ Meister c. B., Trib. Federal Suisse, 9 decembre 1892, Sirey 1893 IV 16.

${ }^{51} R G$ (Reichsgericht), 27.05.1908 - Rep. VI 484/07, at para. 3; 5.
} 
France $^{52}$ recognised this from a very early date, especially with the framework of civil law. Interestingly, federal legislation in Germany has only recently defined the treatment contract, and no mention of access to medical files exists. ${ }^{53}$ The German courts consider it an implied case-law right. ${ }^{54}$ Some civil law states, such as Germany, recognised the right to inspect medical records as part of the patient's informational right to self-determination in the late 1970s, which also marks the beginning of the development of case law on the subject.

The United Kingdom's approach to the matter is based upon sec. 32 of the Administration of Justice Act 1970, which enabled access to medical records. Before the adoption of this legislation, it was only possible to request the production of medical records with a subpoena. ${ }^{55}$ In rare instances, the issue of producing medical records for malpractice litigation was also related to by the Scottish courts, ${ }^{56}$ while the European Court of Human Rights discussed it several times. In the trial of Gaskin against United Kingdom (1989), a young man, who had been in the custody of various municipal bodies in the 1960s and 1970s, was reported to have various health complications, including psychiatric problems. He was unable to find a job and decided to sue the local authorities in Liverpool, blaming them for negligent care. In order to obtain the required evidence, he applied to the court requesting access to all the relevant documents held by the municipal bodies, but was refused and lost the suit to the Liverpool City Council. The English Court of Appeals then held that the public interest in preserving a plaintiff's medical records in a fully-confidential mode supersedes the plaintiff's private interest in commencing a medical malpractice action. ${ }^{57}$ This was based upon the regulations adopted by the government, which determined that access to medical files could only be granted if the contributor consented to their release, which was often impossible. The European Court of Human Rights found that the plaintiff had no independent body to appeal to, such as an institution, which could weigh their interests and the public interest in medical record confidentiality equally. Instead, the actual balance was moved towards the contributors. The Court found that such measures were not compatible with the test of a "democratic society". The absence of an independent body to determine issues concerning access to medical records was found to be a violation of the plaintiff's right to privacy, guaranteed by the Convention of Human Rights. ${ }^{58}$

The trial known as M.G. against United Kingdom (1997) was quite similar. The plaintiff was an unfortunate man who wished to obtain knowledge about his childhood, the abuse administered by his father and additional related issues. After

\footnotetext{
${ }^{52}$ Beltzer c. Hospices de la ville d'Auxonne, Cour d'Appel Dijon, 18 mars 1903, Sirey 1906 II 17 , 17-18.

${ }^{53}$ BGBI. I 2013 S. 277, § 630a, Vertragstypische Pflichten beim Behandlungsvertrag.

${ }^{54}$ See decision of the German Federal Supreme Court, BGH, 23.11.1982; VI ZR 222/79, at para. 15.

${ }^{55}$ Davidson v Lloyd Aircraft Services Ltd. [1974] 1 W.L.R. 1042, 1045.

${ }^{56}$ See., Glacken v. National Coal Board, 1951 S.C. 82, 83-84 (Court of Sessions, Nov. 21, 1950); Boyle v. Glasgow Royal Infirmary and Associated Hospitals, 1969 S.C. 72, 81-83 (Court of Sessions, Nov. 22, 1968).

${ }^{57}$ Gaskin v Liverpool City Council, [1980] 1 W.L.R. 1549, 1553-1555 [1979 G. 2754].

${ }^{58}$ Gaskin v United Kingdom, [1990] 1 FLR 167, App. No. 10454/83, Judgment of 7 July 1989, para. 19-28; 34-37; 42-45; 46-49; 50-53.
} 
he was granted access to a limited number of records, he decided to commence a lawsuit for negligent care in his childhood, but the medical records and other documents extant from his earlier life were not sufficient to prove negligence. He therefore desired to gain access to additional documents, but the local social services refused his request. At the trial before the European Court, the defendant's representatives acknowledged that they hadn't given him some documents, claiming this was necessary in order to avoid a breach of his siblings' privacy. However, they denied possessing documents confirming his father's abuse or other information that he requested for the negligence action. At first, the Court determined that the acts of the defendant did not contradict the legislation and case law of the United Kingdom, but at the same time, it affirmed that the plaintiff's legitimate interest in receiving his archival records was as that of the plaintiff's in the case of Gaskin. Since the defendant had brought the actual folder containing the plaintiff's records before the Court, the Court had the opportunity to compare the real and actual amount of records that had been supplied to the plaintiff before the lawsuit had commenced. Like Gaskin, the Court found that the plaintiff also had no independent institution to appeal to, though he would have had such an opportunity after the enactment of the Data Privacy Act 1998 on March 1, 2000. Therefore, the Court decided in favour of the plaintiff. ${ }^{59}$

A decade later, another suit was brought before the European Court concerning the subject. In the case of K. H. \& Others v. Slovakia (2009), eight female plaintiffs found themselves sterile after having given birth and hired a lawyer to inspect their medical records, which they planned to use as evidence at a malpractice litigation against their respective hospitals. The lawyer was refused access to the medical records, and the plaintiffs applied to two trial Courts (in Presov and Krompachy respectively), which allowed their lawyer limited access to the documentation, though photocopying was prohibited. They lost their appeal, and the Presov Court held that courts are competent to subpoena medical records within the proceedings. Later, after the adoption of a new law in Slovakia, the plaintiffs were allowed to inspect their medical records, and one of the women found a short recorded item confirming that she had undergone sterilisation, though her entire medical record had been lost. The European Court, having examined the trial facts, affirmed that the right to inspect medical records is a constituent of the plaintiffs' right to privacy, and thus is guaranteed under Art. 8 of the European Convention of Human Rights. In short, the Court said that it was necessary to define whether such a restriction of access to medical files was compatible with "abuse" (meaning abuse of process). Having done so, the Court found that photocopying the records would not constitute "abuse" in such a case, and concluded that the enactment of a new law would not change the judgment. As the action was filed upon Art. 6, 8 and 13 of the Convention, the Court had to examine each count. The Court determined that the plaintiffs' right to privacy was violated by the defendant, and proceeded to examine whether the claim was actionable upon Art. 6 of the Convention. It held that the medical files requested by the plaintiffs were vitally important as evidence for commencing malpractice

${ }^{59}$ M. G. v United Kingdom, [2002] F.C.R. 289, App. No. 39393/98, Judgment of 24 September 2002 , at para. $9-17 ; 32-32 ; 34-36$. 
litigation, and that the national Courts did not justify the limited access to medical records adequately. The Court had no choice but to find a violation of Art. 8 of the Convention of Human Rights as well, and deemed it unnecessary to examine the count upon Art. 13, as a violation of Art. 6 and Art. 8 had already been affirmed. ${ }^{60}$ Such cases were also brought before the Court of Justice of the European Union, mainly in the late 1970s and early 1980s. These were mostly litigations between ex-EEC employees and EEC bodies, primarily connected with complaints concerning the plaintiff's unfitness to perform the duties placed upon the desired position in the EEC bodies. ${ }^{61}$ In the 2010s, similar cases were adjudicated by the currently-defunct European Civil Service Tribunal, a specialised court within the European Court of Justice (2005-2016). ${ }^{62}$

\section{Portuguese Legislation and Case Law on the Right to Access to Medical Records}

The Portuguese legislation has a number of provisions guaranteeing a right to the inspection of medical records, which involve several laws and bylaws. The main law regulating the subject is the so-called "health information law" (Lei No. 12/2005, "Informação genética pessoal e informação de saúde", or literally "personal genetic information and health information"), enacted in January 2005, which regulates the basic issues regarding access to health information. Separate issues of access to medical records are covered by Lei No. 15/2014 ("Lei consolidando a legislação em matéria de direitos e deveres do utente dos serviços de saúde" - in English "law consolidating legislation on the rights and duties of consumers of healthcare services") as well as LADA-2016, or the law on access to administrative documents, officially Lei No. 26/2016 ("Aprova o regime de acesso à informação administrativa e ambiental e de reutilização dos documentos administrativos" - in English "confirmation of the procedure for access to administrative and environmental information and the reuse of administrative documents"), inasmuch as Portuguese courts consider medical files to be administrative documents. ${ }^{63}$ Additional legal bases for the production of medical records were cited by the courts, involving data protection legislation and some secondary bylaws.

The first Portuguese case to examine the right to access medical records was adjudicated by the Porto Court of Appeals (Tribunal Relacao do Porto). The facts were simple. The plaintiff was involved in a road accident in which he was injured and suffered a partial disability, and desired to receive compensation for his

\footnotetext{
${ }^{60}$ K.H. \& Others v. Slovakia, App. no. 32881/04, Judgment of 28 March 2009, para. 8-9, 10, 11-19, 24-25, 26-27, 38-43, 50-58, 65-69, 73.

${ }^{61}$ Alessandro Moli v. Commission of European Communities, Judgment of 27 October 1977, Case No. 121/76 [1977] ECR 1971, 1978-1980; Emma Mollet v. Commission of European Communities, Judgment of 13 April 1978, Case No. 75/77, [1978] ECR 897, 907-908; Miss M. v. European Commission, Judgment of 10 June 1980, Case No. 155/78 [1980] ECR 1798, 1811-1812.

${ }^{62}$ V. v. European Parliament, Case F-46/09, Judgment of 5 July 2011, para 110 - onward.

${ }^{63}$ Unidade de Saude A c. B..., Acordao do Supremo Tribunal Administrativo, 08.08.2018, Processo 0394/18, Sec. III, 2.
} 
injuries from a local insurance company. He requested his clinical records from a hospital (unnamed in the report) as evidence and was refused. As he intended to use his medical records as trial evidence, he turned to the Court, asking for a court order to compel the hospital to produce these documents. The Court affirmed that the plaintiff had a right to inspect the records and requested that the plaintiff appoint a doctor, to whom the records should be sent (in later case law, this was deemed not to be strictly necessary) ${ }^{64}$ The Court agreed that the provisions of Art. 2-3 of Lei No. 12/2005 guaranteed that health-related information was indeed the property of the person concerned, but at the same time, is not possessed by them, but rather is in the possession of healthcare institutions. Healthcare providers are the repositories of the health records and have a duty to protect their confidentiality, preventing their inspection by third parties, unless authorised to do so by law. For this reason, the plaintiff was free either to keep his medical information confidential at a hospital, or to disclose it to whomever he wished, such as an insurance company or a court of law. The Court thus determined that the plaintiff had a right to request his medical records - either for personal use or to use as evidence in trial, as he was free to dispose of his medical data as he wished. ${ }^{65}$

The central case for Portuguese jurisprudence is the decision of the Supreme Administrative Court of Portugal (Supremo Tribunal Administrativo) in the case of Bernardo ... c. Santa Casa da Misericordia de Lisboa, ${ }^{66}$ which was the hospital's appeal against a decision in favour of the plaintiff). In the given case, the plaintiff «B» was the son of a man, «C.», who was hospitalised with a severe traumatic brain injury, which occurred in June 2014. The father sustained a leftside tetraparesis, as well as speech, behaviour and swallowing disorders. As his father was unable to communicate, the plaintiff and his mother, «D.», as the father's guardians, decided upon all aspects of his treatment. In August 2016, the plaintiff's father underwent nail extraction surgery. Through his lawyer, the plaintiff requested that the hospital provide photographs and other medical records concerning the clinical episode which culminated in this operation. When the hospital did not respond to this request, the plaintiff applied to CADA (Committee on Access to Administrative Documents), complaining that he had not received the requested documents. The committee issued an opinion that the hospital should provide the medical records, but the hospital refused to do so, writing in a letter to the plaintiff's mother, «D.», that the plaintiff had not justified his interest in accessing the medical records, which are subject to confidentiality, and therefore the hospital would not provide any information to a third party. ${ }^{67}$ A subsequent

\footnotetext{
${ }^{64}$ See. $B$ c. C., Acordao do Tribunal da Relacao do Porto, 08.09.2019, Processo No. 2147 / 18.T8AGD.P1, Sec. II.

${ }^{65}$ Acordao do Tribunal Relacao do Porto, 10.03.2008, Processo No. 0850591, Sec. II.

${ }^{66}$ This case name was used in the report of the South Central Administrative Court of Appeals of Portugal. The court report from the Supreme Administrative Court used the name Unidade de Saude A c. B. See Bernardo ... c. Santa Casa da Misericordia de Lisboa, Acordao do Tribunal Central Administrativo, 31.01.2018, Processo 353/17.BESNT.

${ }^{67}$ Unidade de Saude A c. B..., Acordao do Supremo Tribunal Administrativo, 08.08.2018, Processo 0394/18, Sec. II, 1-11.
} 
request was dismissed, after which the plaintiff decided to apply to the court and request that a subpoena be issued for the medical records. ${ }^{68}$

The Administrative Court of Sentra (Tribunal Administrativo e Fiscal Sintra, TAF Sintra) ordered the hospital to produce the documents, confirming that the plaintiff had a legitimate interest in obtaining his father's medical records. The defendant appealed the judgment at the South Central Administrative Court (Tribunal Central Administrativo Sul, TCAF), losing the appeal. The appellate court found that the son needed the medical records as a guardian of a sick or disabled person so he could decide whether or not to file an action against the hospital for malpractice. Therefore the plaintiff was justified in his request to inspect his father's medical records. ${ }^{69}$ The hospital appealed this judgment as well, turning to the Supreme Administrative Court. The Supreme Administrative Court determined that the action involved a situation in which the health information was not the property of the plaintiff, though it did belong to his father. The Court, analysing the national legislation, confirmed that the term 'health data' covers all the information directly or indirectly linked to the current-day health condition of a person, or presumable future condition, whether they are alive or deceased, as well as their clinical history. ${ }^{70}$ These health records are the property of the person concerned (the patient), while the hospitals are the repositories (holders) for the records, and the person concerned has a right to access their health records. Third parties may have access to this information with the holder's consent. ${ }^{71}$ Obviously, the law imposes a duty of confidentiality on the hospitals. The court referred to art. 2 (1) and 5 (1) of Lei No. 26/2016 (LADA-2016), upon which the citizens have a right to access administrative documents concerning their existence, and hospital records fall within the scope of nominative administrative documents; thus, the procedure is due under: Art. 3 (b); 6 (5); 7 of Lei No. 26/2016; art. 3 (a); 5 (1) (a); 11 (5) of Lei No. 67/98 (law on data protection); Art. 2, 3, 4 of Lei No. 12/2005. In order to further clarify this matter, the Supreme Administrative Court announced a set of rules concerning access to medical records and their proprietary status:

1) 'Health-related personal data' refers to all the information covering facts directly or indirectly linked to one's health;

2) The health records are the property of the patient concerned, and the hospitals (or, as referred to in the judgment, health system units) are the repositories of these records;

3) The possessor of the records has a right to inspect them (unless prohibited by law, e.g. where it may be harmful to the patient). In any case, they must state the purpose of the inspection and the type of health records they wish to inspect;

\footnotetext{
${ }^{68}$ Ibid, Sec. II, 11-13.

${ }^{69}$ See. Bernardo ... c. Santa Casa da Misericordia de Lisboa, Acordao do Tribunal Central Administrativo, 31.01.2018, Processo 353/17.BESNT, Sec. II.2, 1.2.

${ }^{70}$ Unidade de Saude A c. B..., Acordao do Supremo Tribunal Administrativo, 08.08.2018, Processo 0394/18, Sec. III, 2.

${ }^{71}$ Ibid, Sec. III, 2.
} 
4) Third parties may access the health records with the consent of the holder, only to the extent to which they consented in a designated document;

5) The access to health records is provided to the holder through a physician who will serve as an intermediary, if so requested;

6) If it is impossible to ascertain the will of the patient concerning access to their records, this will be accomplished by a physician who will serve as an intermediary;

7) In case of third party access, they must demonstrate that their request has a relevant direct, personal, legitimate and constitutional protected interest. Once this is accomplished, the court (in case a trial ensues) shall consider the case in the context of the principle of proportionality of fundamental rights (presumed as data privacy) and the principle of open administration justifying access to administrative documents (health records).

8) Only information necessary for the third party's legitimate interests may be communicated (i.e. not all the information contained in health records);

9) Hospitals (health system units) must prevent unauthorised access by third parties, based upon data protection legislation ${ }^{72}$.

The court considered that the plaintiff requested access to the health records concerning the nail extraction performed on his incapacitated father. The plaintiff was not the possessor of the health information, and thus, upon the legal rules described hereinabove, had to demonstrate a relevant interest in obtaining the health records. The Court determined that the plaintiff's interest was justified. ${ }^{73}$ The Court also noted that the initial purpose for examining the health records, meaning the reason for the "relevant interest", was to decide whether the hospital could be blamed for malpractice. According to the court, the son had a right to sue the hospital for malpractice, as his father would have had; moreover, the son is apparently not a random conjectural third party, and the Court agreed that the son had a justifiable cause to access his father's health records. The Court dismissed the hospital's appeal. ${ }^{74}$

Contemporary Portuguese case law also includes a judgment concerning access to medical records provided to third parties who are not relatives of a certain patient. The case of Companhia de Seguros de Vida S.A. contre USF-Alma Mater (the officially reported names of the parties to the proceedings) was an appeal against the decision of TAF Sintra (Tribunal Administrativo e Fiscal), which dismissed a subpoena request from $S$. to produce the medical file of a patient, one Manuel, who was deceased by the time of the action. these files were being held by the defendant, the Regional Health Administration of Lisbon and Vale do Tejo. The plaintiff, an insurance company, had insured Manuel in February 2006. It was claimed that at the time, Manuel signed a waiver, upon which the insurance policy coverages excluded professional ailments or workplace

\footnotetext{
${ }^{72}$ Ibid, Sec. III, 3

${ }^{73}$ Ibid, Sec. III, 4.

${ }^{74}$ Ibid, Sec. III, 5-6.
} 
accidents. $^{75}$ The insurance contract (which is quite clear) contained a clause stipulating that the policy payment will be paid only once a series of supporting documents were produced. In the case of death, this included the following documents: the death certificate, a medical certificate stating the cause of death, a copy of an autopsy report and a number of additional documents, detailed in the insurance policy. ${ }^{76}$ Manuel died shortly before 2018 (the court report does not specify the precise date of his death and its cause, but it was seemingly a progressive disease). On February 22, 2018, the plaintiff company sent a letter of request to the Health Administration to obtain the insured's medical file, or alternatively, an updated list of his ailments and the dates of diagnoses. The plaintiff attached a copy of the health declaration signed by Manuel in 2006. The board did not comply with the request, in fact, they did not even respond. ${ }^{77}$ The plaintiff then filed a complaint with CADA (the Commission on Access to Administrative Documents) under Art. 16 of the LADA-2016, claiming that Manuel had previously authorised the insurance company to access his medical records, and indicated a medical advisor to whom the documents were expected to be sent. $^{78}$

Despite the fact that CADA found in favour of the plaintiff, ${ }^{79}$ the plaintiff still did not receive the medical file. ${ }^{80}$ The plaintiff then applied to the court to obtain the necessary documents. The trial court dismissed the claim, on the basis that a) the plaintiff did not possess an explicit (meaning written) authorisation to access the deceased man's health data (though in fact, the CADA assumed that the deceased had previously provided his explicit authorisation to give access to all necessary health data to the insurer via a medical adviser) and b) the plaintiff did not demonstrate a "constitutionally protected interest" in accessing the health records as a third party. ${ }^{81}$ The plaintiff impugned the said judgment to the administrative court of appeal, holding that the insurance company had a legitimate interest in obtaining the Manuel's medical file, which was required to assess whether the company was obliged to pay the sum covered in the policy. The plaintiff also claimed that upon the provisions of the insurance policy, the (now deceased) insured man had expressly authorised the company to access his medical records. ${ }^{82}$ Thus, the insurance company claimed that it had a "direct, personal and legitimate interest" in obtaining the necessary (though not all) medical records. The appellate court found that the assumptions upon which the

\footnotetext{
${ }^{75}$ Companhia de Seguros de Vida S.A. contre USF-Alma Mater (Administracao Regional de Saude de Lisboa e Vale do Tejo, IP), Acordao do Tribunal Central Administrativo Sul de 06.06.2019, Processo 1264/18.9BESN, Sec. II, A-B.

${ }^{76}$ Ibid, Sec. II, D.

${ }^{77} \mathrm{Ibid}$, Sec. I, 5-7; Sec. II.1.I, Sec. E-G.

${ }^{78}$ Ibid, Sec. II.1. I, 1-2.

${ }^{79}$ CADA, Pacerer No. 441/2018 (Opinion No. 441/2018).

${ }^{80}$ Companhia de Seguros de Vida S.A. contre USF-Alma Mater (Administracao Regional de Saude de Lisboa e Vale do Tejo, IP), Acordao do Tribunal Central Administrativo Sul de 06.06.2019, Processo 1264/18.9BESN, Sec. II.1.II; Sec. I, 1-7.

${ }^{81} \mathrm{I}$ bid, Sec. I, 10.

${ }^{82}$ Ibid, Sec. II, 2.
} 
Portuguese law permits third party access to medical records were fulfilled by the plaintiff. ${ }^{83}$ Thus, the Court affirmed the following:

1) The ownership of health information, involving clinical data, examinations, the results of analyses, interventions and diagnoses (as personal data) belongs to the person to whom it relates upon Art. 3 (1) of Lei No. 12/ 2005;

2) The insured person's declaration constitutes authorisation to health data access under the existing legislation;

Therefore, the Court decided to grant the appeal and summon the defendant to produce the requested medical records. ${ }^{84}$

A late 2019 decision by the Porto Court of Appeals dealt with the scope of the right to access medical files and restrictions pertaining to this right. It seems that the legislative provisions did not provide precise exemptions, so the court had to elaborate them itself. In this case $(B$. contre $C$. according to the original court report), the plaintiff applied to the court for a judgment to compel a dental clinic to give him the medical records relating his dental treatment as well as records manufactured within his examinations. Some time ago, the plaintiff had contracted an unnamed dental clinic for dental treatments, consultations and examinations. At some point, the plaintiff was strongly dissatisfied with the services of the clinic, and attempted to find an alternate clinic in order to finish the prescribed course of treatment and undo the damage to his health caused, as he alleged, by negligent treatment provided by the first clinic. The defendant, the dental clinic, refused to give the plaintiff his entire set of medical records, though they did hand over copies of several of them. In its judgment, the Court tried to clarify what is and what is not included within the scope of access to medical records, since the legislation did not provide any exact boundaries. ${ }^{85}$ The Court confirmed that upon art. 3 of Lei No. 12/2005, the health information is the property of the patient, while the hospitals are the repositories of the information, and may not dispose of it in any way other than for healthcare and other activities prescribed by law (Art. 5 of the same law). The Portuguese law, as the Court added, establishes a statutory right to access to medical records (Art. 3 (2) of the same law; Regulation 14/2009 DR 2nd ser. No. 8, 13.01.2009, art. 100 of the Code of Medical Ethics, and Art. 5 (3) of Lei No. 15/2014). Thus, as the Court affirmed, patients have property rights to their medical records (art. 3 of Law 12/2005), and upon the position of the Porto Court of Appeals, people whose respective medical records are kept in hospitals, do not have to use an intermediary to receive their files, or even justify their need for access. ${ }^{86}$

At the same time, it's unclear whether all the existing medical files should be disclosed - e.g. what is the appropriate policy regarding the doctors' private notes

\footnotetext{
${ }^{83} \mathrm{Ibid}$, Sec. II, 2.

${ }^{84}$ Ibid, Sec. III, i; Sec. III / Sec. III, iii; Sec. IV.

${ }^{85}$ B c. C., Acordao do Tribunal da Relacao do Porto, 08.09.2019, Processo No. 2147/18.T8AGD.P1, Sec. II.

${ }^{86} \mathrm{Ibid}$, Sec. II.
} 
concerning the health of the patient? The Court suggested that it would be wise to separate these notes from the clinical records and stated that there must be several types of exemptions allowing access to medical records to be limited. These include:

- A "therapeutic privilege", that is, the facts, if known by the patient, may endanger their life or health;

- Personal notes from the doctor, such as comments on the patient's behaviour (these are the doctors' intellectual property);

- Medical records of health information concerning third parties, if such are contained;

- Medical records provided by third parties (family members, spouses etc).

Upon this corollary, in the case described above the Court decided to grant the plaintiff access only to part of his medical records. ${ }^{87}$

\section{Conclusions}

The patient's right to access their personal medical records, as has been discussed above, derives from the contractual relationship between them and the physician or hospital, and from the patient's right to self-determination, which is acknowledged in the case-law and legislation of various countries worldwide. However, this right is negated by issues of medical confidentiality and the rules of hospital record-keeping, and thus courts are frequently requested to find a suitable balance between the interests at stake. Since the patient's interest in these records is often dictated by the information required for future litigation, one cannot claim that the access to medical records is a somewhat useless right, which may be exercised for diligence or mere curiosity and encroaches upon the hospital recordkeeping practices. As discussed above, some countries chose to adopt appropriate legislation to regulate the issue of access to medical records, while others chose to let it be decided by the Courts, which later elaborated a substantial amount of the principles regarding the scope of access, the rights of the third parties for inspection, the necessity of justifying it, the proprietary status of the medical records and the exemptions or restrictions for access to patients' medical data. Apart from Portuguese case law, the paper observes two models of accessing the health records - the one adopted in England, which is more restricted, and the one in Germany, which is far more liberal.

The Portuguese model is based upon statutory law, but the principles proscribed in the legislation are expounded by the Courts in their respective caselaw, which is the core of the paper. For instance, the Portuguese courts have firmly elaborated the principles upon which a third party may be given the right to access to medical records (whether an insurance company or a relative of an incapacitated patient, who is unable to give their consent or objection), as well as the possible exemptions from the right of access to medical records, which are not mentioned

${ }^{87}$ Ibid, Sec. II. 
in the national legislation. The Portuguese courts have also affirmed the legislative provisions concerning the proprietary rights in patient's medical records, and clarified the issues deriving from them. In fact, cases regarding access to a third party's medical records can seldom be found in the judgments of courts, but the young Portuguese jurisprudence possesses fresh judgments on granting access to patients' files. The current experience of the European Court of Human Rights in this matter is relatively small, but the manner in which the subject is treated in different European countries promises to provide the basis for ECtHR case law (and probably, the future EU legislation). In one of my recent papers, I discussed how the judgments of the German courts may be useful for the jurisprudence of the European Court of Human Rights ${ }^{88}$ in its future cases. The Portuguese model, being substantially younger than the German or English models, has quite a lot of positive features, embracing both legislation and case law, and the principles elaborated by Portuguese judges may also be helpful for the future jurisprudence of national and international human rights Courts.

\section{References}

Feenan, D. (1996). 'Common law access to medical records' in Mod. L. Rev. 59(1): 101 110.

Gründling, J.N. (2011). 'Die Dokumentationspflicht und das Einsichtsrecht des Patienten in die Krankengeschichte' (dissertation) University of Wien, Faculty of Law.

Kenna, T.W. (1973). 'The Patient-Physician Relationship: Present Law and Trends for the Future Implied in Cobbs v. Grant (Comment)' in U.S.S.F.L. Rev. 8:320-342.

Lytvynenko, A.A. (2019). 'Common Law Right to Access to Medical Records: The Commonwealth and European Court of Human Rights Practice' Materials of $7^{\text {th }}$ International Conference of $\mathrm{PhD}$ students and Young Researchers in Law 2.0: New Methods, New Laws, 25-26 April 2019, Vilnius, Lithuania, pp. 196-206.

Lytvynenko, A.A. (2020). 'A Right of Access to Medical Records: The Contemporary Case Law of the European Court of Human Rights and the Jurisprudence of Germany' in Athens Journal of Law 6(1):103 -122.

Lytvynenko, A.A. (2020a). 'Data privacy in the sphere of medical confidentiality: the historical and contemporary case-law of the United States, the European Court of Human Rights and selected Continental Europe states', in Topical Problems of State and Law 83:100-135.

\section{Cases}

\section{Austria}

OGH, 23.5.1984, 1 Ob 550/84.

\section{Belgium}

Bessems c. Le Ministere Public, Cass. 20 juillet 1855, Pas. 1855 I 303.

Bernardine de Neef c. Camille Moreau et Consorts, Cour d'Appel de Bruxelles, 24 mars 1905, BJ 1905.530.

Min. Publ.c. Seutin, Cour d'Appel de Bruxelles, 25 mai 1845, Pas. 1845 II 307.

\footnotetext{
${ }^{88}$ Lytvynenko (2020) at 118-119.
} 


\section{Canada}

Lavere v Smith's Falls Public Hospital, 26 D.L.R. 346 (1915).

\section{$\underline{\text { United Kingdom }}$}

\section{England}

Dunning v United Liverpool Hospitals' Board of Governors, [1973] 1W.L.R. 586.

Deistung v South West Metropolitan Regional Hospital Board, [1974] 1 W.L.R. 213.

Davidson v Lloyd Aircraft Services Ltd., [1974] 1 W.L.R. 1042.

McIvor v. Southern Health \& Social Service Board, [1978] 1 W.L.R. 757.

Church of Scientology v DHSS, [1979] 1 W.L.R. 723.

Gaskin v. Liverpool City Council, [1980] 1 W.L.R. 1549, 1553-1555 [1979 G. 2754].

Ex parte Martin, [1995] 1 W.L.R. 110, 117-119.

\section{Scotland}

Boyle v. Glasgow Royal Infirmary and Associated Hospitals, 1969 S.C. 72, 81-83 (Court of Sessions, Nov. 22, 1968).

Glacken v. National Coal Board, 1951 S.C. 82, 83-84 (Court of Sessions, Nov. 21, 1950).

\section{France}

Min. Publ. c. Doumayrou, Cour de Cass., Cham. crim., 6 Mai. 1836, Dall. Per. 1837 I 246. Carron c. Vallaton, Cour d'Appel de Lyon, 24 Mars. 1876, Sirey 1877 II 200.

Bousquet c. Compaigne le Gresham, Cour de Cass., Cham civ., 1 Mai 1899, Dall. Per. 1899 I 585.

Beltzer c. Hospices de la ville d'Auxonne, Cour d'Appel Dijon, 18 mars 1903, Sirey 1906 II 17.

Bresson c. Min. Publ., Cour de Cass., Cham. Crim., 30 Avr. 1909, Dall. Per. 1911 I 369.

G. c. R., Cour d'Appel de Lyon, 16 juin 1909, Dall. Per. 1910 II 123.

Cons. Aubertin c. V. Perrin, Trib. de Bar-Le-Duc, 15 Oct. 1913, Sirey 1914 II 13.

\section{Germany}

AG Essen, 21.04.1997 - 12 C13/97.

AG Weltzar, 15.08.1978-3C 707/78.

$B G H, 23.11 .1982$; VI ZR 222/79.

$B G H, 31.05 .1983$ - VI ZR 259/81.

$B G H, 02.10 .1984$ - VI ZR 311/82.

BGH, 06.12.1988 - VI ZR 76/88 .

LG Gottingen, 16.11.1978-2 O 152/78.

OLG Bremen, 31.07.1979 - 1 U 47/79.

OLG Köln, 12.11.1981: 7U96/81.

OLG Dïsseldorf, 29.03.2000, Az.:3 Wx 436/99.

OLG Munchen, 19.04.2001 - 1 U 6107/00.

OLG Karlsruhe, 16.08.2017 - 7 U 202/16.

$R G$ (Reichsgericht), 27.05.1908 - Rep. VI 484/07.

\section{Italy}

F.M. contro Casa di Cura Polispecialistica (...) e M.I., Consiglio di Stato, Sezione V., sentenza 28 settembre 2010, no. 7166. 
Vol. 6, No. 3 Lytvynenko: A Right to Access to Medical Records in the Case Law...

Netherlands, The

Hoge Raad, 20 April 2001, NJ 2001, 600; No. C99/030 HR.

Rechtbank Arnhem, 8 August 2005, Prg. 2005, 195, No. 128531.

\section{Portugal}

Acordao do Tribunal Relacao do Porto, 10.03.2008, Processo No. 0850591.

B c. C., Acordao do Tribunal da Relacao do Porto, 08.09.2019, Processo No. 2147/18.T8 AGD.P1.

Bernardo ... c. Santa Casa da Misericordia de Lisboa, Acordao do Tribunal Central Administrativo, 31.01.2018, Processo 353/17.BESNT.

Companhia de Seguros de Vida S.A. contre USF-Alma Mater (Administracao Regional de Saude de Lisboa e Vale do Tejo, IP), Acordao do Tribunal Central Administrativo Sul de 06.06.2019, Processo 1264/18.9BESN.

Unidade de Saude A c. B..., Acordao do Supremo Tribunal Administrativo, 08.08.2018, Processo 0394/18.

\section{Sweden}

Socialnämnden i Danderyds kommun, Kammratt Stockholm, 17 Sep. 2014, fall 5348-14 (2014).

\section{Switzerland}

H. c. M. et V., Arret de la Ire Section civile du 25 octobre 1918, BGE 44 I 322.

Meister c. B., Trib. Federal Suisse, 9 decembre 1892, Sirey 1893 IV 16.

\section{United States of America}

Agnew v. Parks, 172 Cal. App. 2d 756 (1959).

Oliver v. Harborview Medical Center, 94 Wash.2d 559 (1980).

Pyramid Life Insurance Co. v. Masonic Hospital Assn. of Payne County 191 F. Supp. 51 (W.D. Okla. 1961).

\section{European Civil Service Tribunal (International Court, defunct)}

V. v. European Parliament, Case F-46/09, Judgment of 5 July 2011.

\section{European Court of Human Rights (International Court)}

Gaskin v. United Kingdom, [1990] 1 FLR 167, App. No. 10454/83, Judgment of 7 July 1989.

K. H. \& Others v. Slovakia, App. no. 32881/04, Judgment of 28 March 2009.

M. G. v United Kingdom, [2002] F.C.R. 289, App. No. 39393/98, Judgment of 24 September 2002.

\section{European Court of Justice (International Court)}

Alessandro Moli v. Commission of European Communities, Judgment of 27 October 1977, Case No. 121/76 [1977] ECR 1971.

Emma Mollet v. Commission of European Communities, Judgment of 13 April 1978, Case No. 75/77, [1978] ECR 897.

Miss M. v. European Commission, Judgment of 10 June 1980, Case No. 155/78 [1980] ECR 1798. 